\title{
International Experience in Business Processes Improving on the Base of Architectural Approach
}

\author{
Luigi Fici
}

Pavel Malyzhenkov *
pavel_mlzh@unitus.it

Maurizio Masi

Fabrizio Rossi

\begin{abstract}
Standardization is the pinnacle of the quality management instruments, which is vital for satisfying customer needs and ensuring sustainable development of business. The ISO 9001:2015 (Quality Management Systems, QMS) standard requires organizations to use the process approach. This paper proposes to use architectural approach for analysis and improvement of business processes for implementation of the ISO 9001:2015 standard.
\end{abstract}

Keywords: Business process, Enterprise architecture, Architectural approach, ISO 9001:2015, Quality management system, Standardization

\section{Introduction}

Modern trends in the development of industrial enterprises are characterized by changes in factors affecting their functioning: innovations and new technologies, increasing competition, changing customer requirements for product quality (the concept of product quality from the perspective of its compliance with customer requirements has developed in market economy). Satisfying the needs of customers is the main objective of any enterprise. Product quality is one of the most important customer requirements, therefore, in order to ensure the successful development of an enterprise, it is necessary to manage the product quality, to evaluate and analyze relevant targets and predict the processes affecting it.

* Research Fellow, Department of Economics, Enterprise, Engineering and Social Sciences, University of Tuscia, Viterbo, Italy. 
Thus, the issue of quality management is of vital importance in this context. Quality management is an operational activity carried out by the managers and personnel of the enterprise, influencing the process of creating products in order to ensure its quality by performing the functions of quality planning and quality control, communication (information), developing and implementing measures and making decisions on quality.

There are various ways to solve this problem, one of which is standardization. This instrument represents the pinnacle of the evolution of quality management, therefore quality management is largely based on standardization in modern conditions. In other words, it's impossible to improve a process unless it isn't standardized [Imai, 1986].

Through formalization of business processes, development and implementation of norms and rules an enterprise can streamline its operations for the benefit and with participation of all stakeholders. The ISO 9000 standards are one of the most common and a special place among them is occupied by the ISO 9001:2015 "Quality Management Systems. Requirements" standard concerning the process of creation and implementation of the quality management systems. The use of this standard can be a strategic decision that allows to effectively manage the quality and get the following benefits from it [ISO, 2015]:

- to provide products that meet the customer requirements and create opportunities to improve customer satisfaction;

- to ensure sustainable development of an enterprise;

- to implement technological development of an enterprise in the framework of improving the business processes by focusing on modern information technologies;

- to eliminate inconsistencies and errors quickly;

- to provide products of better quality and reduce losses from inconsistencies;

- to take involvement of employees to a new level, which contributes to the improvement of internal business processes of an enterprise;

- to improve brand image and customers loyalty.

\section{The Architectural Methodological Approach and its Application to QMS Field}

The need to represent a holistic view of the enterprise is fulfilled by a concept of Enterprise Architecture (EA) which is defined as a set of models and definitions describing the structure of an enterprise, its subsystems and the relationships between them, terminology to employ and guiding principles for design and future evolution [Alaeddini M. et. al., 2016]. EA development is a continuous iterative process which may be approached using EA frameworks including tools, techniques, process model, artefacts descriptions and guidance for EA design. EA frameworks implicitly ensure the achievement of a specific IT-business alignment level. However, they do not distinguish between different alignment perspectives: most of approaches claim that EA development must start with the business strategy and structure definition followed by supporting IT infrastructure and application portfolio design. Whereas diverse misalignment situations require different design approaches. And IT may and should be used in an innovative way as an enabler for renewed or even completely new business strategies, products and services, organization forms and processes. 
International Experience in Business Processes Improving on the Base of Architectural Approach

The purpose of enterprise architecture is to optimize across the enterprise the often fragmented legacy of processes (both manual and automated) into an integrated environment that is responsive to change and supportive of the delivery of the business strategy.

Today's CEOs know that the effective management and exploitation of information through IT is a key factor to business success, and an indispensable means to achieving competitive advantage. An enterprise architecture addresses this need, by providing a strategic context for the evolution of the IT system in response to the constantly changing needs of the business environment [Tan F.B., Gallupe R.B., 2006].

Furthermore, a good enterprise architecture enables to achieve the right balance between IT efficiency and business innovation. It allows individual business units to innovate safely in their pursuit of competitive advantage. At the same time, it ensures the needs of the organization for an integrated IT strategy are met, permitting the closest possible synergy across the extended enterprise.

The quality management system is both an instrument for improving the quality of an enterprise, a way of organizing business processes that ensures achievement of the planned goals through customers' satisfaction, and a specific model described in the ISO 9001:2015 standard. The introduction of a quality management system in accordance with the ISO 9001:2015 standard implies documented business architecture of an enterprise.

One of the examples of EA methodological frameworks is represented by a high-level approach The Open Group Architecture Framework (TOGAF) [The Open Group Architecture Framework (TOGAF Version 9.1)] to design an enterprise architecture. It provides an approach for designing, planning, implementing, and governing an enterprise information technology architecture in according to its business goals.

Business architecture is one of the elements of the EA - a comprehensive description (model) of all key elements and relationships between them (including business processes, technologies and information systems), as well as the process of supporting changes in the business processes of an enterprise on the part of information technology (Fig. 1).

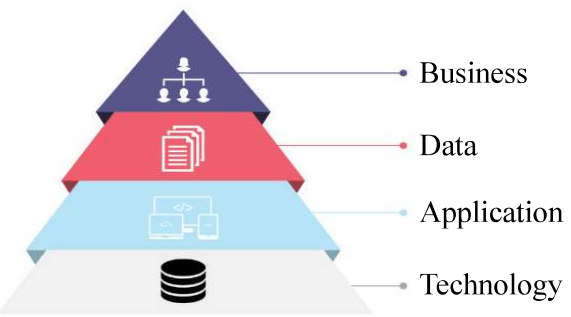

Figure 1. Enterprise Architecture according to TOGAF framework [TOGAF].

The objects of the enterprise architecture are the existing business processes and their supporting organizational, administrative and technical systems utilizing IT-technology. Thus, business processes are a central element of building both an enterprise architecture and quality management system, which allows us to conclude that the architectural approach to the problem under investigation is applicable [Kononov Yu., 2017]. 
International Experience in Business Processes Improving on the Base of Architectural Approach

The modeling of the enterprise architecture and the integration of the quality management system in it is aimed at improving business processes, which will ensure the quality of the enterprise as a whole - reliability, sustainability, technological leadership, investment attractiveness, innovation, employee satisfaction, financial stability. It shows a comprehensive description of the key elements and inter-elements relations.

Development of a quality management system demonstrates the importance of using the architectural approach (describing business architecture of the enterprise) as management instrument for a production enterprise [Peskov E., 2016]. The architectural approach implies clear objectives: company's goals, the specification of the organizational structure, the description and optimization of business processes, the development and distribution of documentation, the automation of processes and the implementation of a quality management system (Fig. 2).

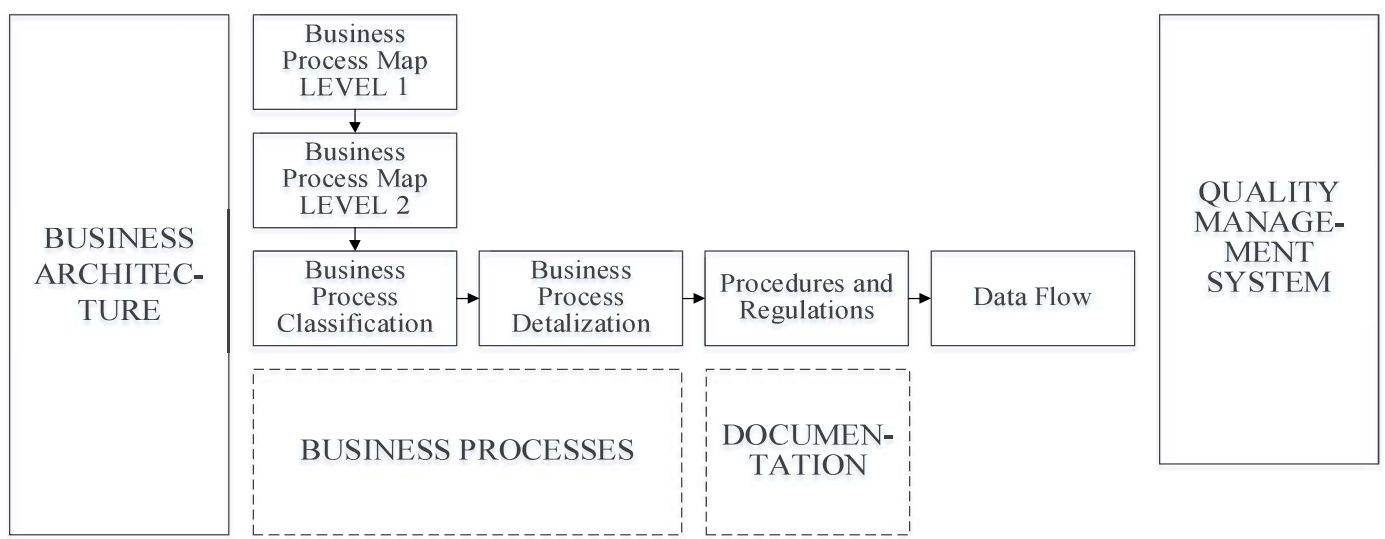

Figure 2. Business architecture and $Q M S$.

Rationally organized and documented enterprise architecture allows to ensure compliance with the requirements of the international standard ISO 9001:2015 in the field of business processes identification and documentation. And vice versa, the need for a quality management system can direct attention to the initialization of the enterprise architecture development, paying attention to those processes and resources that are crucial for enterprise quality management. Thus, quality management and enterprise architecture form a natural combination: the first is devoted to the development, documentation, control, measurement and improvement of business processes, and the latter determines how these processes will be organized and implemented.

\section{Business Case Description: «AS-IS» Architectural State}

Let us analyze how the architectural approach was implemented for transition to the standard ISO 9001:2015 on the example of an enterprise functioning in the field of manufacturing. The key goal is to describe the initial (AS-IS) and desired (TO-BE) states of the enterprise, conduct the gap-analysis and determine the scope of work that is required to make a transition to the desired state of the enterprise.

In the view of the increasing production plan and the expansion of the product range, it becomes necessary to introduce a new approach to quality management. Thus, the company's management decided to implement the ISO 9001:2015 standard and get certified (conformity assessment). 
International Experience in Business Processes Improving on the Base of Architectural Approach

ISO 9001:2015 is an international standard [ISO 9001:2015, Quality management systems - Requirements, 2015] that establishes requirements for quality management. Standard summarizes a global experience in the field of quality management and is applicable absolutely to any enterprise, regardless of the scope and size. According to the standard, the quality management system of an enterprise should be based on seven principles of quality management (Fig. 3).

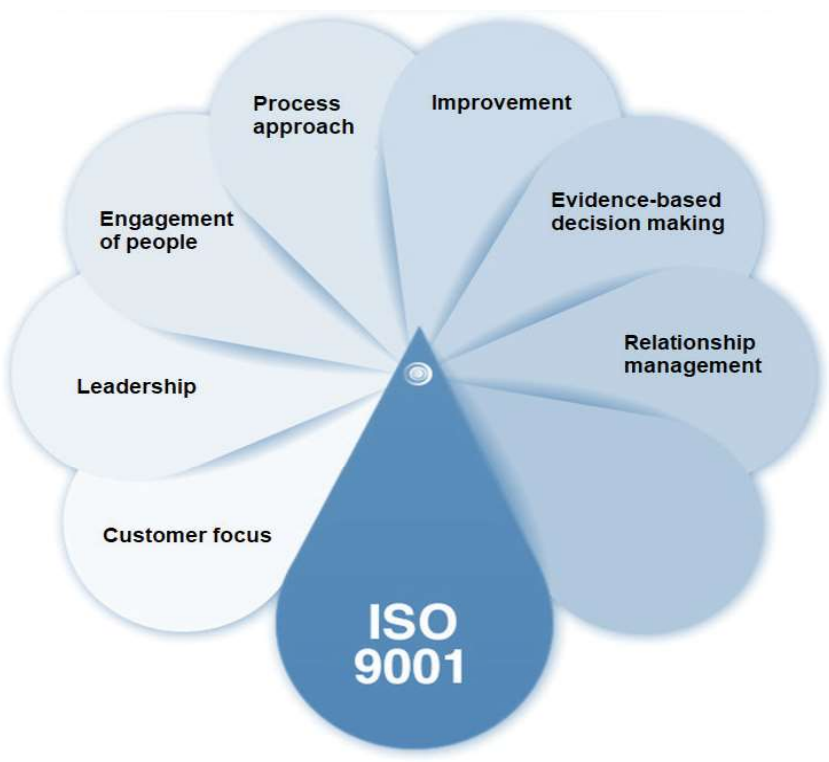

Figure 3. Quality management principles [ISO].

The structure of ISO 9001:2015 can be displayed in a schematic representation of the process approach [ISO 9001:2015, Quality management systems - Requirements, 2015]. Such a representation shows the interconnection of all sections of the standard (Fig. 4).

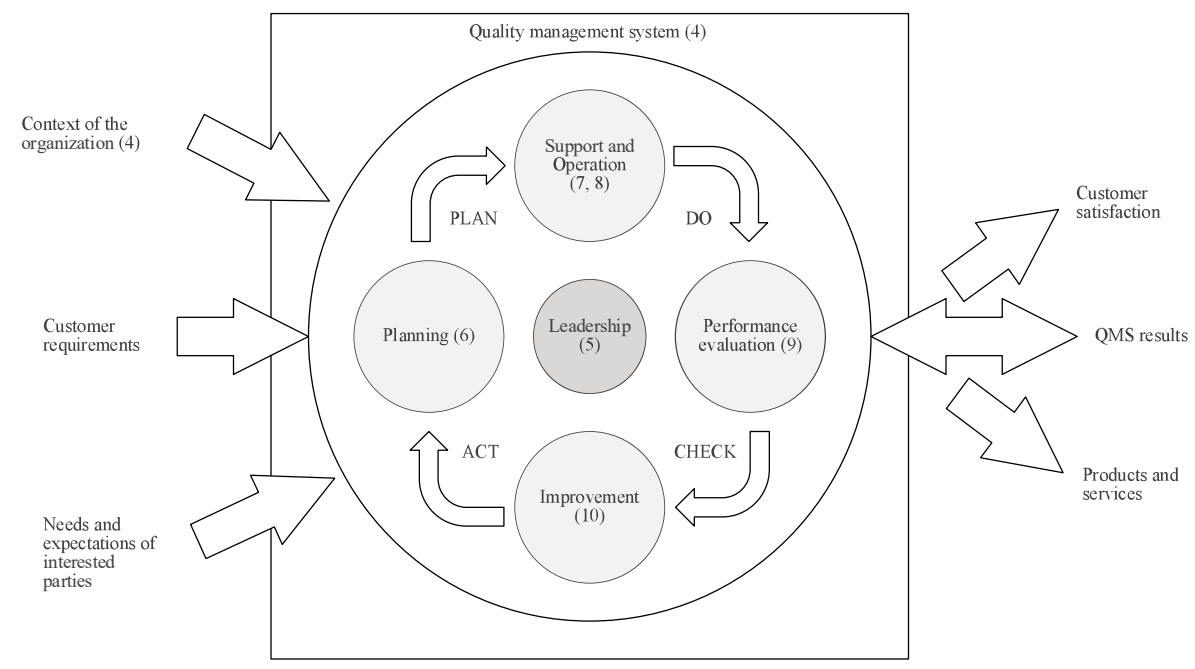

Figure 4. The ISO 9001:2015 structure [ISO].

The ISO 9001:2015 standard is a set of requirements that are necessary for the implementation and successful operation of the quality management system:

NJMSR V. 3 Issue 2(2019) 65 
International Experience in Business Processes Improving on the Base of Architectural Approach

- adherence to the quality management principles established by the standard;

- use of the process approach (allows an enterprise to manage its processes and ensure their interaction);

- risk-oriented thinking (allows to identify risks that can lead to deviation from the planned results of processes and quality management system, develop and implement risk management measures to prevent and minimize the likelihood of risk realization);

- documenting processes and procedures, as well as managing documented information;

- conducting internal audits (allows to determine the compliance of the quality management system with the requirements of the standard and to analyze the effectiveness of its functioning).

The table below shows the initial state of the enterprise (AS-IS) at the level of the business architecture taking into account the analysis of the requirements of ISO 9001:2015 (Tab. 1):

\section{Table 1}

The Initial State of the Enterprise Business Architecture (AS-IS)

\begin{tabular}{|c|c|c|}
\hline $\begin{array}{c}\text { Architecture } \\
\text { level }\end{array}$ & Scope & The initial state of the enterprise (AS-IS) \\
\hline & Goals & $\begin{array}{l}\text { The company has set annual goals, which include the } \\
\text { achievement of the following targets: volume of production, } \\
\text { product quality, percentage of productivity of production } \\
\text { personnel) }\end{array}$ \\
\hline & Strategy & $\begin{array}{l}\text { It was decided to implement the ISO } 9001: 2015 \text { standard in } \\
\text { order to perform quality management (implementation of a } \\
\text { quality management system and certification for compliance } \\
\text { with the ISO } 9001: 2015 \text { standard) }\end{array}$ \\
\hline & Implementation & ISO $9001: 2015$ \\
\hline & $\begin{array}{l}\text { QMS } \\
\text { Documenta-tion }\end{array}$ & $\begin{array}{l}\text { There is no documented first-level information necessary for } \\
\text { the implementation and functioning of the quality management } \\
\text { system (quality policy, quality objectives, quality manual). } \\
\text { Existing documentation can be further developed for use in } \\
\text { the quality management system. }\end{array}$ \\
\hline \multirow[t]{5}{*}{$\begin{array}{l}\text { Business } \\
\text { architecture }\end{array}$} & $\begin{array}{l}\text { Risk } \\
\text { management }\end{array}$ & $\begin{array}{l}\text { Risk management process is developed insufficiently (there } \\
\text { is no documented procedure for risk management, there is } \\
\text { no documented information on risks and measures for their } \\
\text { management) }\end{array}$ \\
\hline & $\begin{array}{l}\text { Internal } \\
\text { audits }\end{array}$ & $\begin{array}{l}\text { The implementation of the internal audit system is at an early } \\
\text { stage. There is no documented procedure for conducting } \\
\text { internal audits and developing and implementing corrective } \\
\text { measures. There are no trained internal auditors }\end{array}$ \\
\hline & $\begin{array}{l}\text { Business } \\
\text { processes }\end{array}$ & $\begin{array}{l}\text { Situational (as problems are identified) approach to the } \\
\text { development and description of business processes. } \\
\text { Development of process management is at an early stage. } \\
\text { Process performance targets are not defined }\end{array}$ \\
\hline & $\begin{array}{l}\text { Organizational } \\
\text { structure }\end{array}$ & Organizational structure is defined \\
\hline & $\begin{array}{l}\text { Allocation of } \\
\text { responsibilities }\end{array}$ & Every department has its responsibility distribution matrixe \\
\hline
\end{tabular}

Characteristics of the initial state of the enterprise (AS-IS) at the level of the information systems architecture (Tab. 2): 
International Experience in Business Processes Improving on the Base of Architectural Approach

Table 2

The Initial State of the Enterprise Information Systems Architecture (AS-IS)

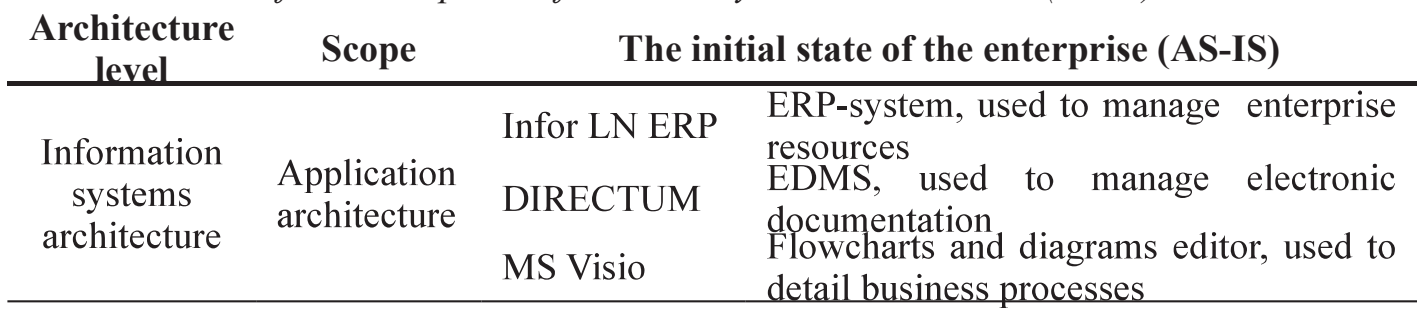

\section{4. "TO-BE" Architectural State Description: Migration Plan}

The desired state of the enterprise (TO-BE) is an enterprise with an effectively functioning quality management system meeting the requirements of ISO 9001:2015 standard (Tab. 3, 4).

Table 3

The Desired State of the Enterprise Business Architecture (TO-BE):

\begin{tabular}{|c|c|c|}
\hline $\begin{array}{l}\text { Architecture } \\
\text { level }\end{array}$ & Scope & The desired state of the enterprise (TO-BE) \\
\hline \multirow[t]{7}{*}{$\begin{array}{l}\text { Business } \\
\text { architecture }\end{array}$} & Goals & $\begin{array}{l}\text { The company has set quality goals in the framework of the } \\
\text { quality management system }\end{array}$ \\
\hline & Strategy & $\begin{array}{l}\text { The quality management system is implemented and } \\
\text { successfully functioning. The certificate of conformity to } \\
\text { standard ISO } 9001: 2015 \text { is received }\end{array}$ \\
\hline & \multicolumn{2}{|c|}{ Implementation of ISO 9001:2015 } \\
\hline & $\begin{array}{l}\text { QMS } \\
\text { Documenta- } \\
\text { tion }\end{array}$ & $\begin{array}{l}\text { The first-level documentation for introduction and successful } \\
\text { operation of the quality management system (quality policy, } \\
\text { quality objectives, quality manual) has been developed. } \\
\text { The second-level documentation has also been developed } \\
\text { (procedures on document flow, regulatory documentation, risk } \\
\text { analysis, supplier evaluation, management of non-conforming } \\
\text { products, internal audits, corrective measures). }\end{array}$ \\
\hline & $\begin{array}{l}\text { Risk } \\
\text { management }\end{array}$ & $\begin{array}{l}\text { A risk management procedure has been developed, a risk } \\
\text { register has been created (contains information on existing } \\
\text { risks, their significance, responsibility distribution and risk } \\
\text { management measures) }\end{array}$ \\
\hline & $\begin{array}{l}\text { Internal } \\
\text { audits }\end{array}$ & $\begin{array}{l}\text { Training of internal auditors was carried out. A system of internal } \\
\text { audits has been implemented: procedure for conducting internal } \\
\text { audits, developing and implementing corrective measures has } \\
\text { been developed. Internal audits of all business processes were } \\
\text { conducted. }\end{array}$ \\
\hline & $\begin{array}{l}\text { Business } \\
\text { processes }\end{array}$ & $\begin{array}{l}\text { Process management s implemented - business processes of the } \\
\text { enterprise are considered as interrelated elements of the system: } \\
\text { there is a map of the first level processes, a map of the second } \\
\text { level processes, business processes were detailed. The targets } \\
\text { and performance criteria of business processes are determined. }\end{array}$ \\
\hline
\end{tabular}


International Experience in Business Processes Improving on the Base of Architectural Approach

Table 4

The Desired State of the Enterprise Information Systems Architecture (TO-BE)

\begin{tabular}{cccl}
\hline $\begin{array}{c}\text { Architecture } \\
\text { level }\end{array}$ & Scope & The desired state of the enterprise (TO-BE) \\
\hline $\begin{array}{c}\text { Information } \\
\text { systems } \\
\text { architecture }\end{array}$ & $\begin{array}{c}\text { Application } \\
\text { architecture }\end{array}$ & DIRECTUM & $\begin{array}{l}\text { ERP-system, used to manage enterprise } \\
\text { EDSources } \\
\text { documentation }\end{array}$ \\
& BPMS iGrafx & $\begin{array}{l}\text { Instrument for modeling, analysis and } \\
\text { management of business processes }\end{array}$ \\
\hline
\end{tabular}

To determine the scope of work required for the transformation of the enterprise (AS-IS à TO$\mathrm{BE}$ ), management has appointed responsible employees and set up a working group. The next step was to create a work structure of the ISO 9001:2015 standard implementation (Fig. 5), as well as a project implementation plan (Tab. 5).

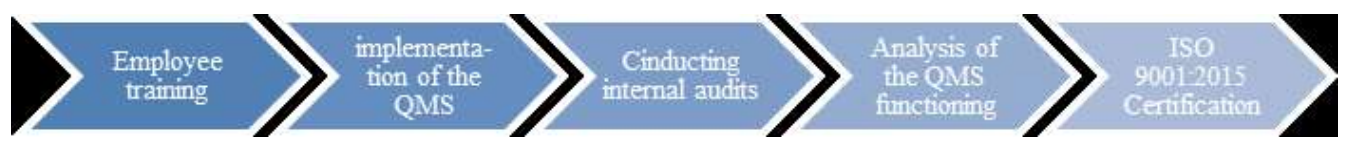

Figure 5. Structure of work.

Table 5

\section{Project Implementation Plan}

\begin{tabular}{|c|c|c|c|c|c|c|c|c|c|c|}
\hline \multirow{2}{*}{ Stage } & \multirow{2}{*}{ Description } & \multicolumn{4}{|c|}{2017} & \multicolumn{5}{|c|}{2018} \\
\hline & & WW4-34 & WW35 & WW36-45 & WW43-51 & WW3-4 & WW5-9 & WW10 & WW10-12 & WW13 \\
\hline 1. & Employees training & & & & & & & & & \\
\hline 1.1 . & Working group training (ISO 9001:2015) & & & & & & & & & \\
\hline 1.2. & $\begin{array}{l}\begin{array}{l}\text { Training "Business processes of the quality management } \\
\text { svstem" }\end{array} \\
\end{array}$ & & & & & & & & & \\
\hline 1.3 . & Internal audits training & & & & & & & & & \\
\hline 1.4 . & Training for production masters (corrective measures) & & & & & & & & & \\
\hline 2. & ISO 9001:2015 Implementation. Developing business proce & sses and do & cumenta & ion & & & & & & \\
\hline 2.1 . & Analysis of the requirements of the ISO $9001: 2015$ standard & & & & & & & & & \\
\hline 2.2 . & Analysis of existing documentation & & & & & & & & & \\
\hline 2.3. & $\begin{array}{l}\text { Analysis of existing process model and regulatory } \\
\text { documentation, use of quality management system in existing } \\
\text { process documentation }\end{array}$ & & & & & & & & & \\
\hline 2.4 . & $\begin{array}{l}\text { Discussing the QMS business processes and documentation. } \\
\text { Conducting the gap-analysis }\end{array}$ & & & & & & & & & \\
\hline 2.5 . & $\begin{array}{l}\text { Creating documentation development plan. Developing the } \\
\text { documentation according to the plan }\end{array}$ & & & & & & & & & \\
\hline 2.6. & $\begin{array}{l}\text { Creating business processes development plan. Developing } \\
\text { business processes }\end{array}$ & & & & & & & & & \\
\hline 3. & Preparing for internal audits. Conducting internal audits & & & & & & & & & \\
\hline 3.1 . & Conducting internal audits & & & & & & & & & \\
\hline 3.2. & $\begin{array}{l}\text { Preparing audit reports. Developing and implementing } \\
\text { corrective measures }\end{array}$ & & & & & & & & & \\
\hline 4. & The QMS performance analysis & & & & & & & & & \\
\hline 4.1 . & Conducting the QMS analysis & & & & & & & & & \\
\hline 4.2 . & $\begin{array}{l}\text { Preparing a performance report. Conducting management } \\
\text { review }\end{array}$ & & & & & & & & & \\
\hline 5. & Preparing for certification. Certification audit & & & & & & & & & \\
\hline 5.1 . & Preparing for the first stage of certification audit & & & & & & & & & \\
\hline 5.2 . & Certification audit. Stage 1 & & & & & & & & & \\
\hline 5.3 . & $\begin{array}{l}\text { Developing and implementing corrective measures according to } \\
\text { the results of the certification audit (stage } 1 \text { ) }\end{array}$ & & & & & & & & & \\
\hline 5.4 . & $\begin{array}{l}\text { Conducting an internal audit. Developing and implementing } \\
\text { corrective measures (if necessary) }\end{array}$ & & & & & & & & & \\
\hline 5.5 . & Certification audit. Stage 2 & & & & & & & & & \\
\hline
\end{tabular}


International Experience in Business Processes Improving on the Base of Architectural Approach

The key areas of work are the development of quality management system documentation and the introduction of a process approach. In accordance with the requirements of the standard, documented information of the first and second levels is developed (Fig. 6):

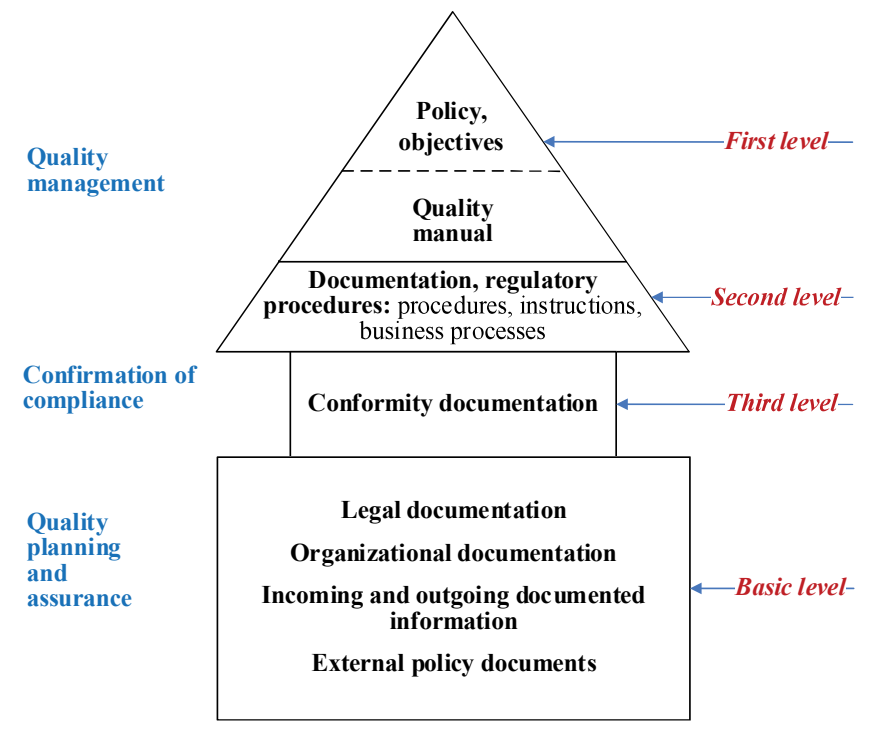

Figure 6. Documented information structure.

The introduction of process management within the framework of implementing the quality management system implies the consideration of all types of enterprise activities as a managed system of processes that is aimed at achieving its targets and meets the requirements of customers and other interested parties. All processes of the system are interrelated [Lapshin V., Yamashkin Y., 2015].

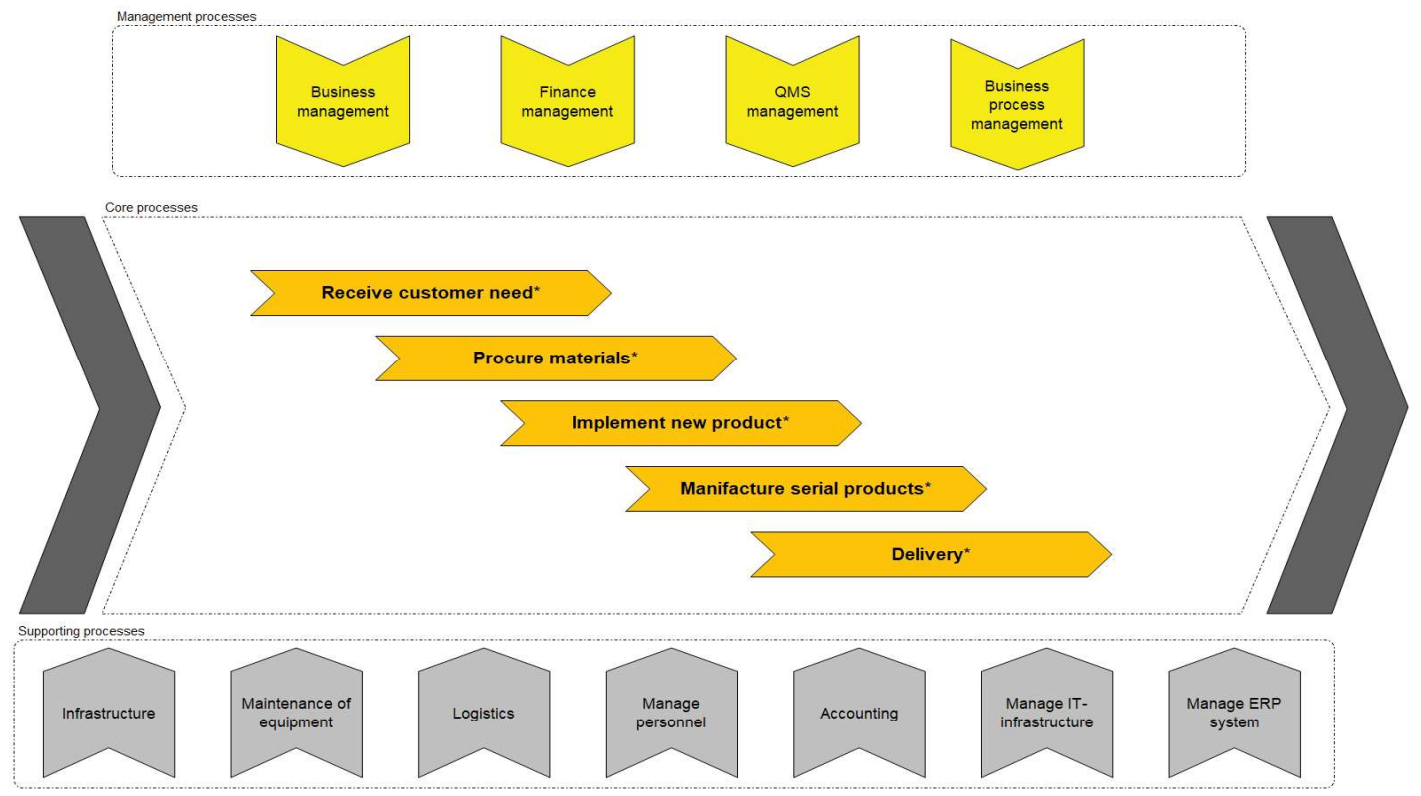

Figure 7. Business process map (level 1). 
To implement the process approach, it is necessary to develop a complete model of the processes that create value for customers. This model can be represented as a top-level process map (Fig. 7). The second level of the process map and a plan for detailing business processes are also created. For each business process we defined:

- process owner;

- process boundaries and process goals;

- inputs and outputs;

- targets and performance criteria of the process.

To implement the principles of the process approach, the company implements the iGrafx BPM system. The system allows to model and analyze business processes, as well as manage them. The introduction of iGrafx helps to accelerate the creation of a graphical representation of processes (process detailing is carried out in BPMN notation) and to manage the life cycle of business processes. Let us take a look at the the main process "Serial production" (Tab. 6). It includes three second-level processes, which have their subprocesses (detailing).

Table 6

Serial Production Process

\begin{tabular}{|c|c|c|c|c|c|}
\hline \multicolumn{2}{|c|}{ Level 1} & \multicolumn{2}{|c|}{ Level 2} & \multicolumn{2}{|r|}{ Detailing } \\
\hline Code & Title & Code & Title & Code & Title \\
\hline \multirow{14}{*}{$\mathrm{CP} 4$} & \multirow{14}{*}{$\begin{array}{l}\text { Serial } \\
\text { production }\end{array}$} & \multirow{6}{*}{ CP4_1 } & \multirow{6}{*}{$\begin{array}{l}\text { Planning } \\
\text { and } \\
\text { production }\end{array}$} & CP4 11 & Planning of details \\
\hline & & & & CP4 12 & Production of details \\
\hline & & & & CP4_1_3 & Planning of assembly groups \\
\hline & & & & CP4_1_4 & Production of assembly groups \\
\hline & & & & CP4_1_5 & Painting \\
\hline & & & & CP4_2_1 & $\begin{array}{l}\text { Management of techonogical } \\
\text { documentation }\end{array}$ \\
\hline & & \multirow{4}{*}{ CP4_2 } & \multirow{4}{*}{$\begin{array}{l}\text { Ensuring } \\
\text { the } \\
\text { production } \\
\text { process }\end{array}$} & CP4_2_2 & Changing route time \\
\hline & & & & CP4_2_3 & Management of techonogical process \\
\hline & & & & CP4_2_4 & $\begin{array}{l}\text { Confirmation of orders and changes } \\
\text { in delivery dates }\end{array}$ \\
\hline & & & & CP4_2_5 & $\begin{array}{l}\text { Ensuring the safety of materials, } \\
\text { parts and products }\end{array}$ \\
\hline & & \multirow{4}{*}{ CP4_3 } & \multirow{4}{*}{$\begin{array}{l}\text { Production } \\
\text { equipment }\end{array}$} & CP4_3_1 & $\begin{array}{l}\text { Management of technological } \\
\text { equipment }\end{array}$ \\
\hline & & & & CP4_3_2 & $\begin{array}{l}\text { Replacement and repair of broken } \\
\text { instruments }\end{array}$ \\
\hline & & & & CP4_3_3 & Replacement of consumables \\
\hline & & & & CP4_3_4 & Metrological support of production \\
\hline
\end{tabular}

\section{Results and Discussion}

The paper addresses the issue of quality management system development on the base of enterprise architecture approach. It was proposed as an attempt to align a practical business case with the requirements of ISO standard. When estimating the required investments in the 
International Experience in Business Processes Improving on the Base of Architectural Approach

quality management system implementation (achieving compliance with the ISO 9001:2015 standard), several types of costs are defined - implementation costs and operating costs. The first type of costs can be divided into two groups: the costs of direct implementation and the cost of certification. Operating costs are understood as costs for maintaining the quality management system and its improvement. The cost model for the implementation of the management system is shown in Fig. 8:

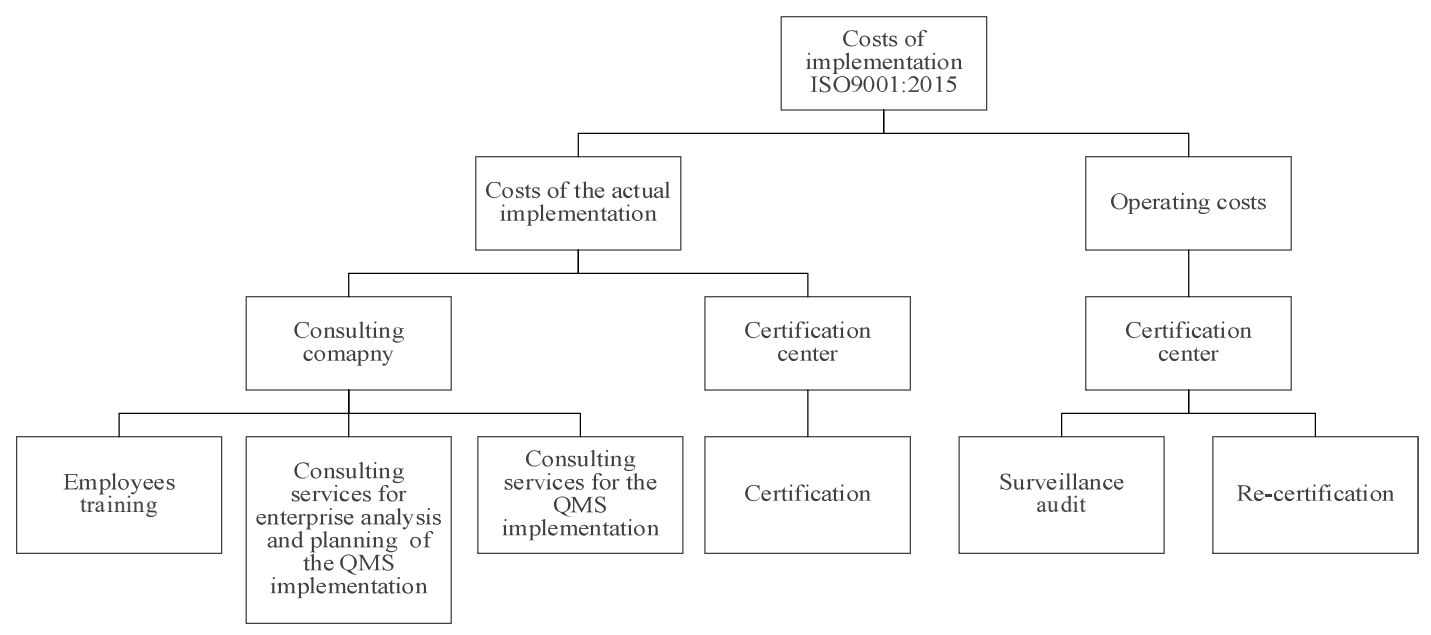

Figure 8. Cost model of the implementation of the QMS.

Another important task is to assess the benefits of implementing the ISO 9001:2015 standard. Advantages can be quantifiable and non-quantifiable, the model is shown in Fig. 9:

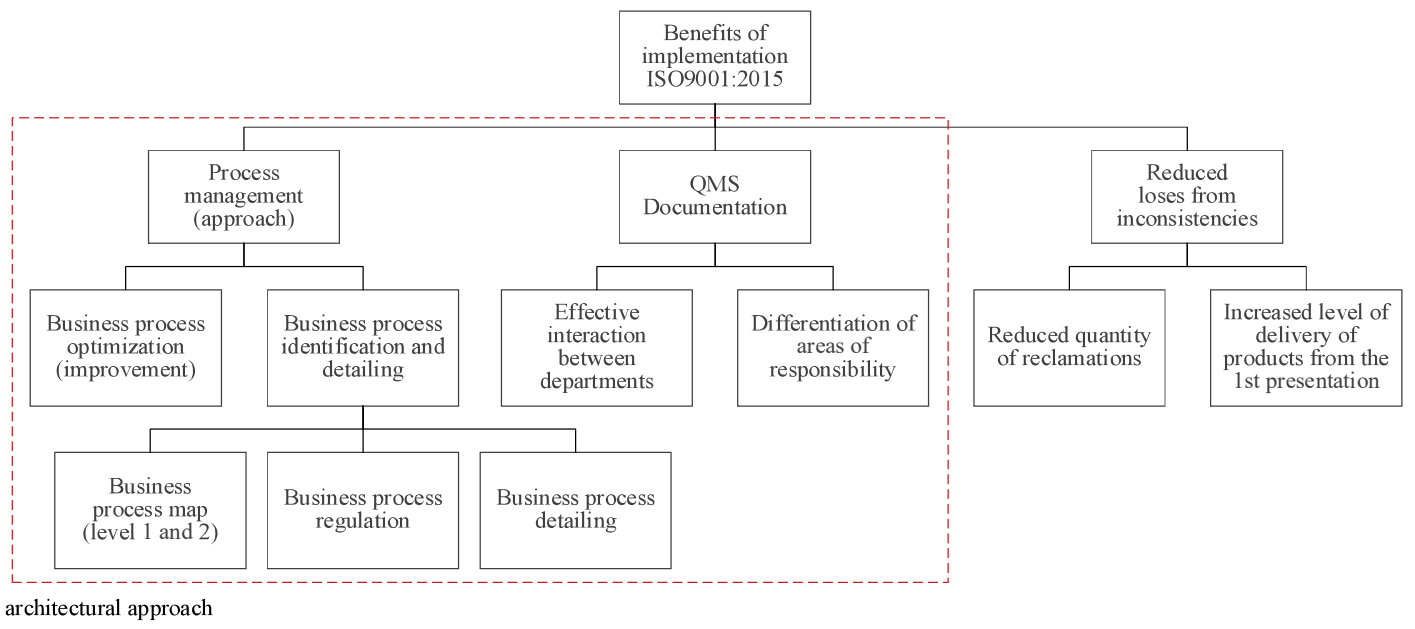

Figure 9. Benefits of implementing the ISO 9001:2015.

Fig. 10 reflects the quantifiable effect of the implementation of the quality management system - the statistics on received complaints (reclamations) from customers (the introduction of the management system started in May 2017): 


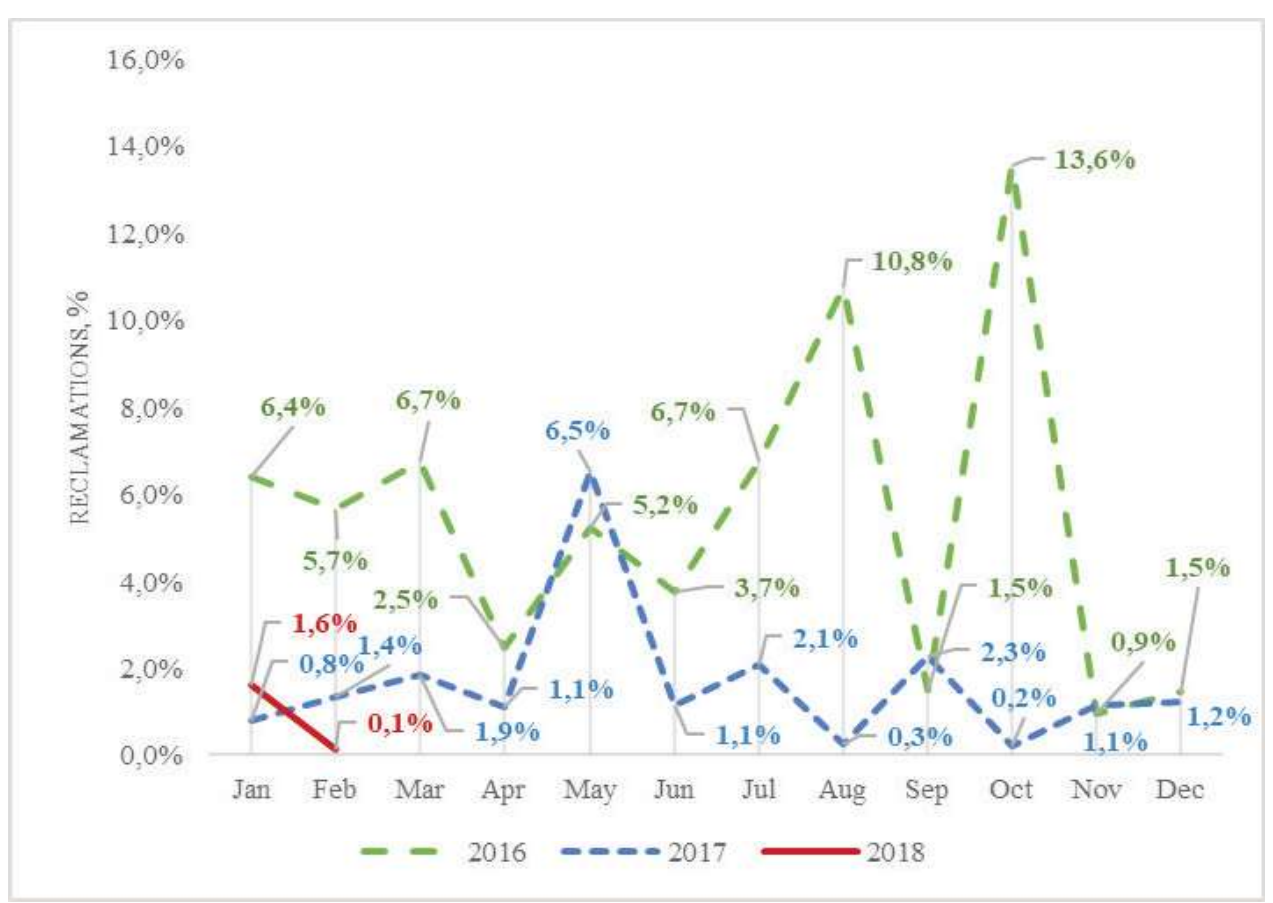

Figure 10. Reclamations.

As a result of the formation of the business process architecture based on the international standard ISO 9001:2015, and the analysis of the results obtained, it is possible to draw a conclusion on the effectiveness of applying the architectural approach to improving business processes of the enterprise. The architectural approach provides continuous management at the interface of single processes within the system, as well as their combination and interaction. Understanding the cause-and-effect relationships between system factors, processes and results allows us to find levers for managing business processes, i.e. develop, manage and improve business processes in order to create added value for customers and other interested parties.

Further research activities follow but are not limited to the following branches:

1. extending the research onto the usage of other architectural approaches and tools (Archimate, BPMN etc.);

2. a deeper specification of each TOGAF phase for different QMS adoption steps;

3. formalization of the model for the resulting EA evaluation;

4. practical application of the proposed framework taking into account such business factors as industry sector, organizational size and type of strategic positioning.

\section{References}

Alaeddini, M., Asgari, H., Gharibi, A., \& Rashidi Rad, M. (2016). Leveraging business-IT alignment through enterprise architecture - an empirical study to estimate the extents. Information Technology and Management, 18, 55-82.

Imai, M. (1986). Kaizen: The key to Japan's competitive success. McGraw-Hill Education, New York. 
International Experience in Business Processes Improving on the Base of Architectural Approach

ISO International Organization for Standardization. http://www.iso.org.

ISO 9001:2015 (en) Quality management systems — Requirements (2015). https://www.iso. org/obp/ui/\#iso:std:iso:9001:ed-5:v1:en.

Kononov, Yu. M. (2017). Principles and approaches to improvement the business process management system of an industrial enterprise. Available via eLibrary. https://elibrary. ru/item.asp?id=29384277.

Lapshin, V.,S., \& Yamashkin Y.,V.(2015). Business Process ManagementBased onArchiterctual Approach. Available via eLibrary. https://elibrary.ru/item.asp?id=25035882.

Peskov, E.V. (2016). Business Processes and Business Architecture in Modern Business World. Available via eLibrary. https://elibrary.ru/item.asp?id=26128180.

Reich, B.H., \& Benbasat, I. (1996). Measuring the linkage between business and information technology objectives, MIS Quarterly, 20, (1) 55-81.

Reich, B.H., Benbasat, I. (2000). Factors that influence the social dimension of alignment between business and IT objectives, MIS Quarterly, 24(1) 81-113.

Sabherwal, R., \& Chan, Y.E. (2001). Alignment between business and IS strategies: A study of prospectors, analyzers and defenders. Information Systems Research, 12(1), 11-33.

Sabherwal, R., \& King, W. (1991). Towards a theory of strategic use of information resources, Information and Management, 20, 191-212.

Schmidt, R., Möhring, M., Härting, R.C., Reichstein, C., Zimmermann, A., \& Luceri, S. (2015). Benefits of enterprise architecture management - Insights from European Experts, Proceedings of Practice of Enterprise Modelling (PoEM) i.e. 235, 223-236.

Tan, F.B., \& Gallupe, R.B. (2006). Aligning business and information systems thinking: A cognitive approach, IEEE Transactions on Engineering Management, 52(2), 223-237.

The Global IT Trends Survey (2016). Retrieved from http://www.globaliim.com/.

The Open Group Architecture Framework (TOGAF Version 9.1). Retrieved from http:/www. opengroup.org/

Venkatraman, N., Henderson, J.C., \& Oldach, S. (1993). Continuous strategic alignment: Exploiting information technology capabilities for competitive success, European Management Journal, 11 (2), 139-149.

Wang, X., Zhou, X., \& Jiang, L. (2008). A method of business and IT alignment based on enterprise architecture, Proceedings of IEEE International Conference on Service Operations, Logistics and Informatics, Vol.1, pp. 740-745. 


\title{
E-leadership in Social Change: A New Paradigm in Bangladesh
}

\author{
Maliha Tabassum * \\ tabassum@bup.edu.bd \\ Priyanka Kundu * \\ priyanka.kundu@bup.edu.bd
}

\begin{abstract}
We are living in a technology driven world where this society, is the most interconnected society ever. Bangladesh, despite having low income, little access to internet and literacy rates, is one of the heaviest social media user countries. According to Global Digital Statshot of Q2 report of 2017, Dhaka, the capital city of Bangladesh, became second Facebook using prone city where youth are the main user. This has made a shift in traditional leadership style where digital platform brought up fresh opportunity to create an effective leadership genre, E-leadership. E-leadership is using digital platform especially social media as leaders virtually influence and instruct followers to achieve a common goal. Despite having significant influence among city youths, insufficient attention was given to this newly emerged leadership style in social media research. Considering this research gap, this study aims to investigate how social media is used as a platform by E-leaders to practice their leadership and how E-leaders perceive the media for social change. The study would analyze two E-leadership based initiatives, 1) Ten Minutes' School (YouTube) and 2) Youth Opportunities Bangladesh (Facebook) where selected contents will be analyzed alongside in depth interviewing of two E-leaders who are the entrepreneurs of two initiatives. Transformational leadership theory is considered as the framework for conceptualizing the context of this study and analyzing collected data.
\end{abstract}

Keywords: E-leadership, Social change, Bangladesh, E-leaders, Influence.

\section{Introduction}

"Yes! I am an e-leader and am working to bring out more and more leaders using social media", Mr. Osama, the founder of Youth Opportunities Bangladesh defined him as an e-leader as he in contributing to change the society through information and communication technology. Not only Mr. Osama, there are significant number of social change makers evolving as e-leaders in current Bangladesh who are incorporating online and social media for reaching bigger audience and putting greater influence over them.

Initially e-leadership term was used only in organizational setting ensuring fast, effective and limitless communication inside a company or an organization. But with the rise of social

* Lecturer, Department of Mass Communication and Journalism, Bangladesh University of Professionals.

* Scholar, Department of Mass Communication and Journalism, Bangladesh University of Professionals. 
media and increased interactivity among social media users, E- leaders are working on a virtual platform for bigger and better goals beyond organizational business and profit. The term has evolved for making the work field different by using social media, so as their work and responsibilities.

For most of the E-leaders the target prosumer is youth. In fact, study found most of the youtubers making online video content are young by themselves and youths are following them because of their relativity (they can relate themselves with the youtuber) and attainability (they can achieve the same) (Sarah, 2016). That is why e-leaders can attract and engage youths (especially the teenagers) with their activities and thus have an impact on social behavior (Westenberg, 2016). The situation is equally appropriate for current Bangladesh.

To find out the relevance and new paradigm of social change making and influencing the community, in the study two different cases- Youth Opportunities Bangladesh and 10 Minutes School, are examined, to find out how the two e-leadership platform are bringing change in the society. The two leaders and founders of the above enterprises- Mr. Osama and Mr. Sadiq, were interviewed to know their aims and objectives to be realized through their platforms. Contents of their Facebook and YouTube page of the month September 2019 were also analyzed to understand the pattern of their subjects.

Following the transformational leadership theory and KAP-Gap concept, the data were analyzed. It is found that e-leadership and e-leaders of Bangladesh are continuously coming with new and innovative ideas, using social media to reach audiences, working to put something positive for the community. Although in a country like Bangladesh, there always remains some technical challenges such as- internet connection, education and others.

\subsection{Definition of Terms: What is E-leadership and who are the E-leaders?}

The concept of E-leadership has evolved time to time, with different names. It was Marshall McLuhan who first coined the word 'Global Village' to describe a new era of communication where the world will be interconnected by technological breakthrough (McLuhan, 1963). This breakthrough was apparent in this time, no doubt; but not like today. Today we have the most interconnected society ever which has given birth to another new technologically driven phenomenon 'Virtual Team' .The concept of 'Virtual Team' and 'Virtual Leadership' have already shifted the way we look at the term 'Leadership'. Some researchers find it even more challenging than the traditional one as the leaders have to cross the boundary of time, space or even culture and also have to lead without any direct supervision or interaction (Kerfoot, 2010). Gibson and Cohen gave emphasis on the effectiveness on creating shared understanding in a virtual team as it makes the team members interdependent and sets a goal to aim at (2003).

According to a survey of Human Resource Management in 2012, 46\% of all organizations were using virtual teams in their workplace (Lepsinger \& DeRosa, 2015) which gave rise a new terminology 'Virtual Leadership.' Kayworth and Leindner (2002) suggested some characteristics of a successful team leader such as empathy, flexibility, regular communication overall having all the traits of a guide/mentor than a stereotype leader. Malhotra, Majchrzak and Rosen (2007) identified six leadership practices of a successful virtual team leader 1) establish

NJMSR V. 3 Issue 2 (2019) 75 
and maintain trust through the use of communication technology; 2) ensuring distributed diversity is understood and appreciated; 3) manage virtual work-life cycle (meetings); 4) monitoring team progress using technology; 5) enhancing visibility of virtual members within the team and outside in the organization; and 6) enabling individual members of the virtual team to benefit from the team. This term defining leadership in online environments then termed differently as 'E-leadership' by Avolio, Kahai and Dodge in 2001. The term has evolved, making the work field different for E-leaders using social media, so as their work and responsibilities.

As communication and information technologies are the core medium of virtual leadership, the new term 'E-leadership' has made its way in many research works. Pulley and Sessa (2001) defined E-leadership with three specific tasks: setting directions, facing challenge and maintaining commitment which can occur in a multitude of options. According to them, it (E-leadership) is enabled through net, where the individuals (both leader and followers) are linked together into a web of information (Pulley \& Sessa, 2001) and they saw it as a new migration.

This study aims to understand this migration that leads to social change. It focuses specifically on social media-based E-leadership to make this change happen. That is why it is important to determine how E-leaders are working for this social change targeting the youth and how they (E-leaders) perceive the social media by themselves.

\section{Research Background and Questions}

E-leadership is using the digital platform especially social media where E-leaders virtually influence and instruct followers especially youths to achieve a common goal. In Bangladesh it is also new but already managed to create a significant influence among the youth. It has obviously made a shift from traditional leadership style to a brand-new genre of virtual reality-based leadership. However, despite creating huge buzz, insufficient attention has been given to this newly emerged leadership style in social media research. Taking this scenario in consideration, the research questions are as following-

- As the concept of E-leadership is comparatively new in terms of social leadership, do they (the founder of the both initiatives) consider them as E-leader?

- Do E-leaders are facing any challenge? How these newly emerged E-leaders are working to overcome challenges to achieve their goals?

- What are their strategies and how are they perceiving their initiatives in bringing social change among youth?

\section{Research Objective}

The primary objective of this research is to carry out a qualitative study to explore the nature of social change via E-leadership in the context of Bangladesh. In understanding the influence of newly emerged E-leaders the objectives of this research are as the following:

- To identify how social media is used as a platform by E-leaders to practice their leadership across boundaries for bringing positive changes among the youth

- To determine how E-leaders perceive the social media for social change (from their pint of view)

- To understand and evaluate their (E-leaders) strategies of youth engagement 


\section{Literature Review}

\subsection{Concepts and Challenges}

Most of the prior researches done on E -leadership prioritize the use of ICT within an organization to increase efficiency for both leaders and employees. Some studies show dynamic relationship (Avolio \& Kahai, 2003) between E leader and employees inside an organization focusing on how to best manage and lead people when they are not having physical proximity yet doing micro work. Jarvenpaa and Tanriverdi (2003) considered this relationship as dyadic between a firm, its employees, customers and suppliers in a virtual knowledge network to illustrate why the balancing act is so important for the bottom line of the firm.

One study (Cascio \& Shurygailo, 2003) reveals some key challenges for the E-leaders of virtual teams. As his/her team is heterogenous, diverse and scattered it is important for him/her to establish and develop different norms and procedures in team's formation and development.

According to the study virtual teams magnifies the differences between good or bad projects, organizations, teams and leaders. The nature of this team is little tolerance of ineffective leadership which clearly shows one of the risk factors of becoming an E-leader. Establishing proper boundary between home and work, effective communication strategies, encouraging and inspiring emergent leaders within virtual teams and promoting oneness and close cooperation between team members are very much crucial for a successful E-leader (Cascio \& Shurygailo, 2003).

\subsection{E-leadership from educational Perspective}

Gurr (2015) explores the concept of e-leadership and why it is relevant to educational organizations. As education has been extremely ICT mediated, he assumed that this new environment needs this new form of E-leadership for its own betterment. He analyzed different studies in non-education settings and suggested to have more empirical research in education settings to determine whether there are major differences between educational and non-educational environments. He urged for more research work on using E-leadership in educational contexts as according to him, E-leadership is still at an early stage.

\subsection{Changing Leadership Styles}

Another term very much relatable with E-leadership is 'Change Leadership'. Change leadership is the ability to influence and enthuse others through personal advocacy, vision and drive, and to access resources to build a solid platform for change (Higgs \& Rowland, 2000). As most of the E-leaders of existing social media plays the similar kind of role, their contribution can easily be relatable with 'Change Leadership' style using information and communication technology. From the educational point of view, Ghasemi and Hussin (2014) gave emphasis on relevant theories of change leadership which must be practiced in higher education settings. As sustainability brings change, the application of change-oriented leadership style is a great contribution to necessary transformation toward sustainability according to them.

Many researchers saw E-leadership as the other name of transformational leadership. Kevin et al (2003) named it as 'Remote Transformational Relationship' where the leaders have least physical proximity yet having positive and effective outcome. Citing previous researches (Howell \& Avolio, 1993) who denied the effectiveness of remote leadership for a 
transformational leader, claimed to have more involving followers working collectively with shared vision of the future.

Again, some studies relate transformational leaders with the traits of E-leaders. Explaining transformational leadership as a process in which "leaders and followers help each other to advance to a higher level of morale and motivation" (Burns, 2002) According to him it reshapes perceptions, create aspiration and gives motivation to followers. Relating this, Purvanova and Bono (2009) suggest considerable variability in leaders' behavior across faceto-face and virtual teams. Further, transformational leadership behaviors are more strongly linked to performance in virtual than in face-to-face teams. Leaders who increased their transformational leadership behaviors with virtual teams achieved the highest level of overall team performance, according to them.

There is an existing debate regarding the synonymy of two terms 'Charismatic' and 'Transformational leadership'. Although defining this type of leaders Max Weber gave them the title 'superhuman', many scholars (Podsakoff, 1994 ; Conger \& Kanungo, 1998) have found these two terms mutually inclusive to each other using terms like 'minor' or 'modest'. Again some (Bas \& Avolio, 1994) saw it merely as a component of transformational leadership. However, both these components are equally important for an E-leader even if they mean nearly the same type of leadership style.

According to Ilies, Judge and Wagnersaid the purpose of charismatic/ transformational leadership is to create influence by giving motivation. They proposed a model through which the influence of leadership on employee motivation is realized which can happen though affective and cognitive mechanisms. According to them transformational/ charismatic leadership makes the work even more challenging to the followers by involving them tightly with the task or job and thus the motivation is created.

\subsection{Youth and Social Media}

Previous researches have analyzed the impact of social media on youth. Studies (Shabir, Hameed, Safdar, \& Gilani, 2014; Ahn, 2011) found positive influences of social media on youth as a medium of educational supplements and creating educational environment. Again, some researchers (O'Keeffe \& Clarke, 2011) blamed social media for offensive content, sexting and Facebook depression.

The impact of E-leaders on youth especially the youtubers are immense. Westenberg (2016) showed how youtubers change behavior, identification and awareness among teenagers. He did a qualitative analysis by taking in-depth interview of selected teenagers and popular youtubers.

This study found a huge teenager engagement with all these YouTube based E-leaders. They try to follow them, including their clothing lifestyle and sometimes also their way of taking, walking, gesture etc. Most importantly they want to be like them in future. Although huge concerns have been shown for these teenagers because of uncensored contents and also less parental monitoring.

Many researches have been done considering different perspectives and terminologies related to and on the effect of E-leadership. But there are few researches relating 'social media' with 'E-leadership' with 'Youth' and 'Social Change'. Somehow E-leaders and their new style of leading the youth remain untouched in academic research arena. Considering this research 
E-leadership in Social Change: A New Paradigm in Bangladesh

gap, our study will investigate how social media can be used as a platform for E-leadership specially as a new paradigm in social change.

\section{Theoretical Framework}

This study has a theoretical framework built on the 'KAP' study concept. The 'KAP' concept refers to the measurement of changes in Knowledge, Attitude and Perceptions (Kaliyaperumal, 2004) inside a community. Basically, this is a term related to diabetes and how patients, doctors and others are perceiving the idea of this disease, facing and overcoming it. The concept is totally based on medical term which can be applicable to other medical related issues as well like Osteoporosis (Khan, Khan \& Malhi, 2014).

To measure the 'KAP' among communities the most popular method in medical science is survey method, which is popularly named as 'The KAP Survey Model' (Knowledge, Attitudes, and Practices). It is a quantitative method that works both with quantitative and qualitative data aiming to find out the obstacles in behavior change. It paves the way to measure the gap inside the 'KAP' concept. Here the gap refers to the obstacles that hinder the knowledge, attribute and perceptions to the ultimate behavior change of a community (Du Monde, 2016).

In this research, we have taken only the concept of 'KAP' gap, not the whole survey model. To understand E-leadership in social change this study will try to see how E-leadership is working with youths as focal point to change knowledge consumption behavior of social media users. Analyzing two initiatives based on education and career development, this study will explore the contents, nature and notion of both initiatives and how the E-leaders are using social media to minimize the 'KAP' gap of web dependent youth community.

Again, we will consider transformational leadership as one of our conceptual frameworks also. Transformational leadership has four dimensions, popularly known as four 'I's: idealized influence, inspirational motivation, intellectual stimulation, and individualized consideration (Bass, 1985). Based on the work of Elkhani, Soltani and Ahmad (2014) this four I's have these following attributes:

Transformational Leadership Behavior Attributes

\begin{tabular}{|c|c|}
\hline Transformational leadership behaviors & Attributes \\
\hline \multirow[t]{6}{*}{ Idealized (charismatic) influence } & Vision \\
\hline & Trust \\
\hline & Respect \\
\hline & Risk-sharing Delegation \\
\hline & Integrity \\
\hline & Modeling \\
\hline \multirow[t]{3}{*}{ Inspirational motivation } & Commitment to goals \\
\hline & Communication \\
\hline & Enthusiasm \\
\hline \multirow[t]{2}{*}{ Intellectual stimulation } & Rationality \\
\hline & Problem solving \\
\hline \multirow[t]{4}{*}{ Individualized consideration } & Personal attention \\
\hline & Mentoring \\
\hline & Listening \\
\hline & Empowerment \\
\hline
\end{tabular}

NJMSR V. 3 Issue 2 (2019) 79 
As in literature review part, we saw the proven effectiveness of transformational leadership and societal system in virtual environment, in this study we tried to explore all these attributes in the context of E-leadership in social media. Analyzing selective contents of two initiatives, we tried to come to a conclusion on the nature of E-leadership based on two frameworks presented above.

\section{Methodology}

One of the main objectives of this research is to qualitatively explore the nature of social change through E-leadership in social media. To achieve the objectives two initiatives were taken in consideration 1) Ten Minute' School (YouTube Based) and 2) Youth Opportunities Bangladesh (Facebook Based). Both initiatives have their own official websites but interacts more using social media. Ten minutes school is an online educational platform for education development at secondary and higher secondary level along with professional skill development courses. It was founded by internet entrepreneur Ayman Sadiq in the year of 2015. On the other hand, youth opportunities Bangladesh is the largest opportunity discovery platform for youth. Believing in access to information this platform records all available opportunities for youth around the world founded by internet entrepreneur Osama Bin Noor. This study is conducted in two phrases. First of all, content analysis has been done on selective contents of these two E-leadership based platforms. As both of the initiatives are web based, we have taken the contents of the month of September 2019 as the most updated ones. From the content analysis method, we have got the primary data for our research. Based on the findings from primary data, on second phrase, we have taken in depth interviews of two E-leaders (founder of both initiatives) Ayman Sadiq and Osama Bin Noor. From the findings of the second phrase along with the conceptual framework we have come to conclusion on how E-leaders are perceiving and using social media to bring out social change and how they are engaging youths to make that change happen.

\section{Findings}

\subsection{Short Introduction and Rate of Interaction of Youth Opportunities (YO) Bangladesh and 10 Minute School:}

Youth Opportunities basically works to disseminate the information of jobs, internships, scholarships and other opportunities for youth population. It originated in Bangladesh but now it is working throughout different countries. It has its own website and they use their Facebook, YouTube and others social media pages to spread the circulars. Youth Opportunities Bangladesh is a very vibrant page having 3,70,499 like and 50 thousand members. Osama Bin Noor is the entrepreneur of the initiative, Youth Opportunity.

On the other hand, the ' 10 Minute School' is a team of young universities students of Bangladesh who re-designed learning and started on 2015 and started giving teaching through videos. There the youth students make 10 minutes learning videos and release it in their channel. Ayman Sadiq is the founder and the CEO of the e-school , 10 minute school(http;//10minuteschool. com). The CEO of the online school, Ayman Sadiq a Dhaka University graduate who also won the Queen's Young Leaders Award 2018 and the best e-learning award from the Asia Pacific ICT Alliance for his school. (Ayman Sadiq, 2019). 


\subsection{Findings from Content Analysis}

As stated earlier, this study analyzed selective contents of September 2019 for both initiatives as they are the most recently uploaded ones. The findings of the content analysis are as follows:

\subsubsection{Number of Posts:}

In September 2019, the interaction and activity of the Facebook page 'Youth Opportunities Bangladesh' was very high as similar with the other recent months. In total, they shared 65 posts regarding internship, jobs, volunteer opportunities, conferences and so many other things where the highest number of posts was on competitions (18 posts), Event ( 7 posts), international conferences ( 6 posts) and help ( 5 posts). Other than that, they share lots of other issues as well. These posts are mainly collection of others' contents, circular and call for interests. But their own generated contents are very few.

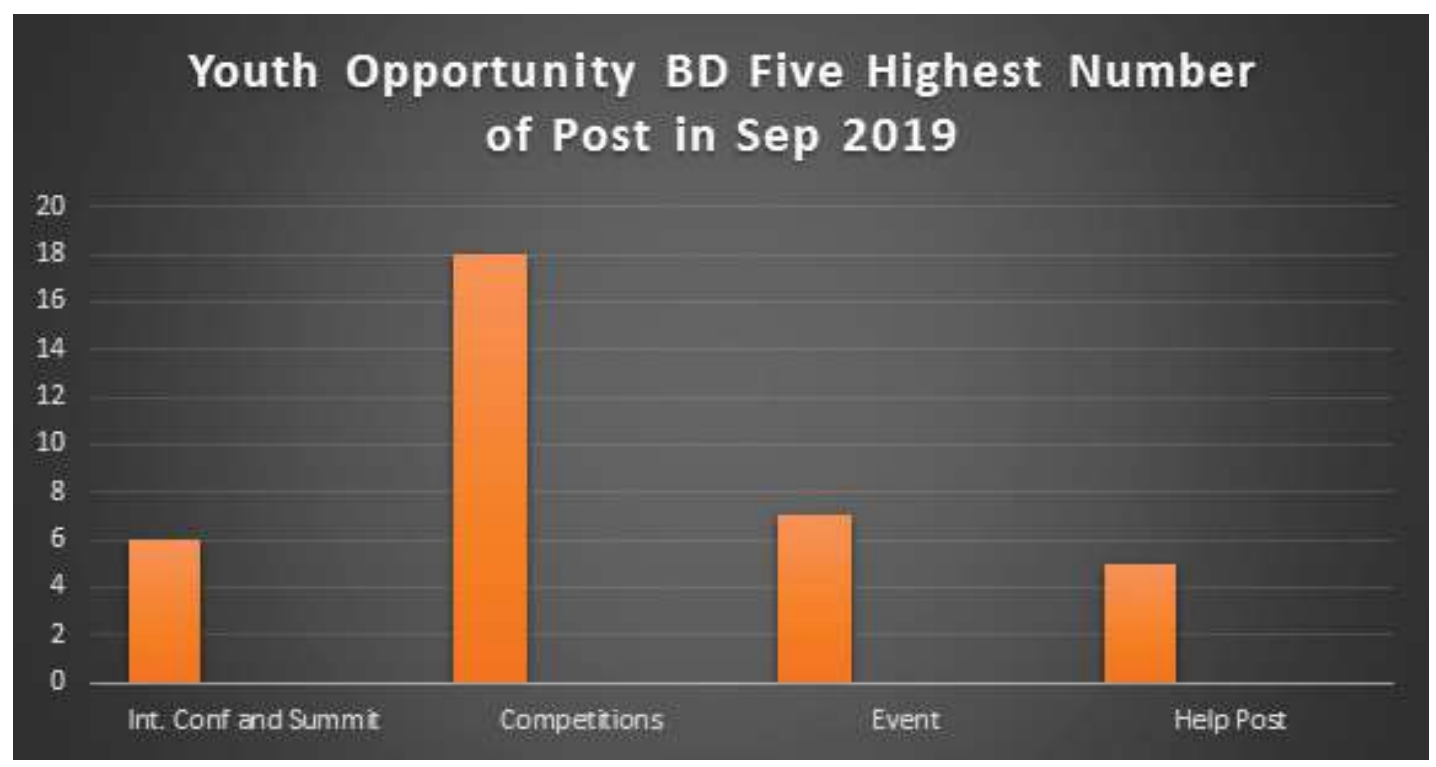

Figure 1. Youth opportunity bangladesh's highest number of Facebook posts.

On the other hand, 10 Minute School has a smaller number of posts comparing youth opportunities. In the month of September, they posted six video contents (including professional skills, English speaking, social awareness, software courses, preposition learning and promotional videos) and 11 interactive posts. One of the notifiable distinctions between two initiatives are Youth Opportunities do not produce contents, they do search and post. On the other hand, in 10 Minute School, every content is produced by themselves. So, eventually their contents are less compering the contents of Youth Opportunities Bangladesh. 


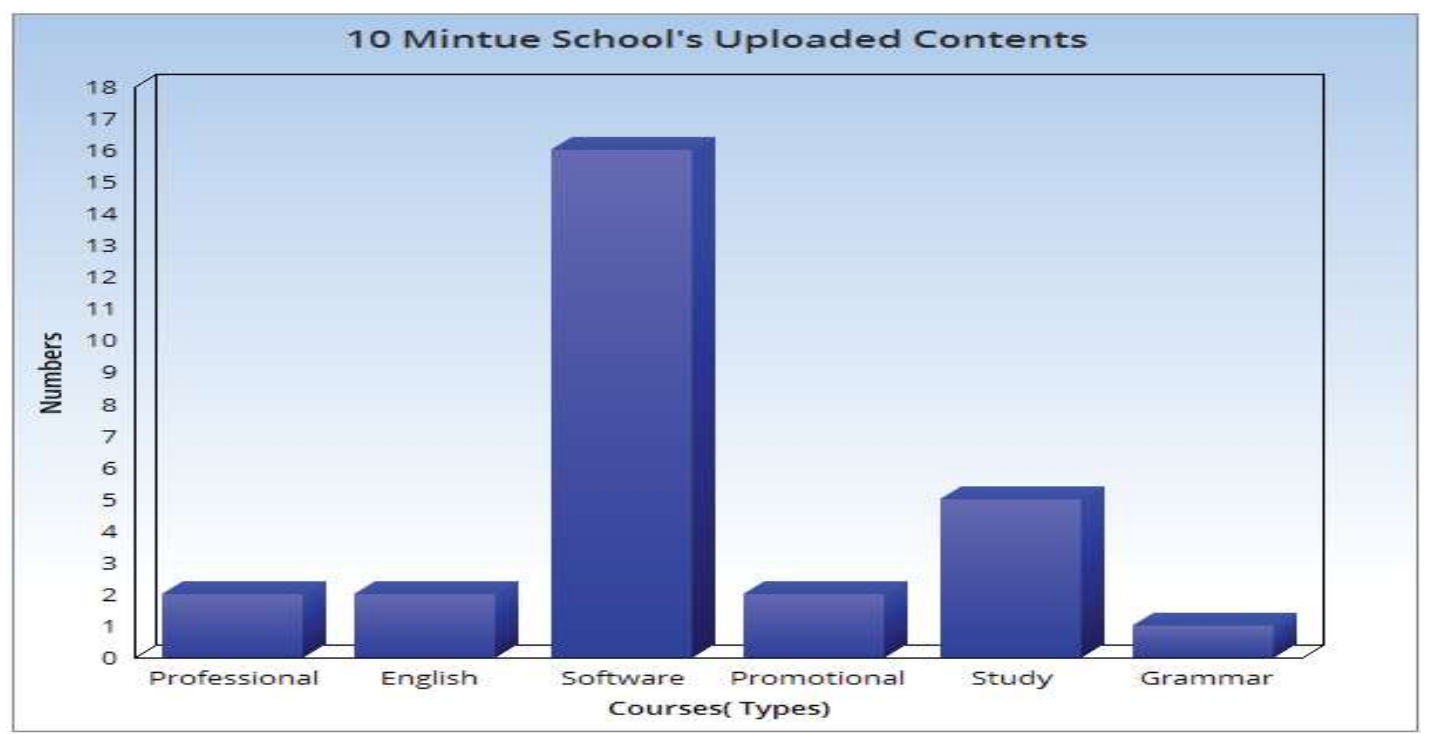

Figure 2. 10 minute school's highest number of You Tube posts.

Although in September 2019, 10 Minute school posts more software courses, that does not at all mean their inclination towards professional contents. 10-minutes school basically makes academic contents targeting school, college and university students. Their inclination towards professional courses in September 2019 shows their gradual expansion of horizon.

\subsubsection{Using More than one platform}

Both Youth Opportunities and 10 Minute school are using several platforms to increase their reach. 10 Minute school have four official You Tube chanel, 10 Minute School Live! 10 Minute School Skill Development Lab, 10 Minute School English Language Club, 10 Minute School LIVE BBA, MBA, Recruitment Test Preparation. Then again in Facebook they have one separate Facebook group and one page. For Youth Opportunities they have separate Facebook pages, One Youth Opportunities original, others are country based. Till now, they have four country-based Facebook pages for Bangladesh, Indonesia, Philippines and Nepal. Slowly they are incorporating more countries to make the platform global.

\subsubsection{Going Global vs Reaching Grassroot}

As mentioned earlier, Youth Opportunities is going global by making networks with more and more countries, their moto is breaking the boundaries where every opportunity counts irrespective to country, gender and culture. Whereas the moto of 10-minute school is reaching the grassroot level within Bangladesh, as they make content in Bangla, targeting Bangladeshi youths.

\subsubsection{Shifting Focus}

Although both initiatives were started in social media, but now they are changing their plan. Currently social media is not the focus for Youth Opportunities Bangladesh, they are giving priority to their Website and App. Latest contents, uploads are mostly found in app and website with an instant notification for the users. On the other side, 10 Minute school is focusing on App but also trying to use Facebook more than the YouTube. 


\subsection{Interview Analysis: E-leadership and Social Change}

"We want to make them future leaders by preparing or facilitating their preparation to face challenging positions by seizing opportunities", Mr. Osama, the founder of the Youth Opportunity Bangladesh quoted while he was asked about the aim of his initiative. To him, the current world is too fast, and to make oneself prepared enough to cope up with the changing dimension of new world, one must take the current challenges, especially the youth. Again, according to him, Bangladesh is a country of huge population and demographic dividend, youth should self-help themselves and they are, through their Youth Opportunity, facilitating the youths.

Mr. Osama's initiative is about the career, skill development and positioning of the current students (school, college and university) in better places by informing them about possible opportunities throughout the world. Whereas, the 10 Minute school is different in nature than the Youth Opportunity. The 10 Minute school is basically a learning hub. It brought a significant change in e-learning and distance knowledge sharing. Mr. Sadiq, the founder of the online school, came up, while sharing his story of starting the innovative, "after getting admission in University of Dhaka, I started taking classes in different coaching centers where I found many rural students could not continue coaching classes for high range of fees. Then I thought, why not I make video of my lessons and spread it over the country without any cost." This event motivated him to start his journey. Gradually he bought a huge contrast in the existing traditional concept of static classroom and school by breaking the barriers of geographical and time of it.

Analyzing the interviews, it can be said that both young leaders dreamt to change the society, bring some positive changes using internet and within five or six years of their starting. They got huge recognition, acceptance and it would not be an overstatement that they managed to bring changes both in education and skill development in country's youths. The number of subscription and like in their page, interaction, sharing their contents vividly express about their successes.

Both can be termed as the modern day's leader who have the courage to take risk, think about the existing problems. They want to bring changes, works for it relentlessly to make that happen. As previously stated, according to the definition of E-leader, Malhotra, Majchrzak, and Rosen (2007) identified six leadership practices of a successful virtual team leader 1) establish and maintain trust through the use of communication technology; 2) ensuring distributed diversity is understood and appreciated; 3) manage virtual work-life cycle (meetings); 4) monitoring team progress using technology; 5) enhancing visibility of virtual members within the team and outside in the organization; and 6) enabling individual members of the virtual team to benefit from the team. These practices are more applicable for internal communication of any corporate office but still it has relevance with the wider sense of e-leaders. In this structure, both Mr. Osama and Mr. Sadiq are e-leaders in Bangladesh who are using internet as a tool and communicating beyond the geographical, social, economic and information barriers. They bet themselves reached over every corner of the country thanks to the internet and social media.

While Mr. Osama was asked whether he identified himself as an e-leader or not, he said "Yes! I am an e-leader and is working to bring out more and more leaders using social media." 
$\mathrm{He}$ also said, resources and opportunists are scattered over differences sources, their task is to gather all of them and make a gateway of opportunities, connecting local and global youths, and make resources available for everyone. To him, it is one kind of empowerment to unlock the inner potential of youth throughout the globe. To make the idea possible, they used social media, especially Facebook, as very an effective platform where the share then circulars' hyperlinks with very short descripting. After clicking the link, it directs the keen to original circular. So, their Facebook pages mediates the connection between the youths and their webpage, the clients and resources.

The founder of the 10 Minute School, Mr. Sadiq is preferred to introduce himself as a teacher who teaches through online media. And to be a successful teacher, it is prerequisite to become a good leader first. He wants to bring a revolution in teaching, classroom and knowledge sharing, and he has done that through his 10 Minute school. He is facilitating e-learning, expanding the lessons beyond the books, classroom, coaching centers and traditional boundaries. That is where he is a successful E-leader and a teacher of E-lesson giving.

After starting his school, he got huge corporate support as well, as the school's name is "Robi, 10 Minutes School". He is also getting aligned with universities, schools and other educational institutions over the countries for growing through offline as well. The interesting thing of the online school is, consumers also can be the producers. Most of the videos are made for his channels by the students of different educational institutions. For the demand of the users, they made at least six channels for specific contents and most of the channels were active.

Both identified the less availability of internet over every corner of the country as a prime challenge for expansion of their enterprises. To them, the frequent policy change of Facebook and YouTube is also another kind of challenges to reach more people. According to Mr. Osama, "Facebook is now more concern about profit making, the company always wants to boost any programme to get more public reach so that if anyone like or follow our page they may not get notification properly for the profit-making policy of Facebook." Still, as the people, especially youths are more dependent on social media, other than using social media they, currently, do not have any short-term solution to reach people. Understanding the challenges of social media, the duo is planning to entertain their own web site and application.

Other than creating positive vibration in the society, the e-leadership is another form of entrepreneurship for ensuring self-help. Both E-leaders are well established through these initiatives at the same time recruiting other youth in their companies. So, through the process, it is possible to help the society as well as help themselves.

\section{Discussion and Conclusion}

In the data analysis and findings part, it was noticeable that both leaders are doing their activity primarily using social media, internet and digital divines and they are trying to change the existing the idea of skill development, knowledge sharing, influencing and bringing social change. They took new media to reach out unknown people breaking the boundaries. The theory, transformational leadership said a leader should manage to provide charismatic influences, inspirational motivation, and intellectual motivation and should have some individualized characteristics. These parameters are and partially relevant for the two 
E-leadership in Social Change: A New Paradigm in Bangladesh

studied e-leaders of Bangladesh. Firstly, Mr. Osama does not always appear publicly, so his charismatic influence is not possible to measure but on the other hand Mr. Sadiq is a very prominent public figure amongst the youth for his charismatic influence through presence on screen- TV and Newspapers- with his individual communication and his motivational speeches. Secondly, both inspirationally motivates the youth- one for skill development and the other for learning. So here, both of them fulfills the requirements to be influencers. Thirdly, they also provide intellectual motivations as well through changing the mind-set of traditional skill development, challenge taking and so one. Lastly, both leaders do empower others, listen to their problems and interact virtually and directly as well. These can be considered under the individualized characteristics.

Through their transformational e-leadership, the two leaders are helping to shrink the KAPGap within the people. They are changing their knowledge level through the online contents, having impact on youth attitude and practices.

So, to conclude, the findings suggested that the both initiatives are very much important for E-leadership in Bangladesh, because they could be identified by their individual enterprises which have greater social benefit and give birth to E-leaders who are currently working for the social change.

\section{References}

Ahn, J. 2011. The effect of social network sites on adolescents' social and academic development: Current theories and controversies. Journal of the American Society for information Science and Technology, 62(8), 1435-1445.

Avolio, B.J., \& Kahai, S.S. 2003. Adding the" E" to E-Leadership: How It May Impact Your Leadership. Organizational Dynamics.

Ayman Sadiq. (2019). Retrieved 28 October 2019, from https://www.forbes.com/profile/ ayman-sadiq/\#2ffda8d9588e.

Bass, B. M., \& Avoilio, B. J. (1994). Improving organizational effectiveness through transformational leadership. Thousand Oaks.CA: Sage Publications.

Bass, B. M. (1985). Leadership and performance beyond expectations. New York: Free Press.

Burns, J.M. (1978). Leadership. New York:Harper \& Row.

Cascio, W.F.,\& Shurygailo, S. 2003. E-leadership and Virtual Teams. Organizational Dynamics, 14.

Chai, S., \& Kim, M.(2012). A socio-technical approach to knowledge contribution behavior: An empirical investigation of social networking sites users. International Journal of Information Management, 32(2), 118-126.

Chuang, Y., \& Schechter, L. (2014). Social networks in developing countries. Annual Review of Resource Economics, 7. 150421150506008. 10.1146/annurevresource-100814-125123.

NJMSR V. 3 Issue 2(2019) 85 
E-leadership in Social Change: A New Paradigm in Bangladesh

Conger, J.A., \& Kanungo, R.N. (1998). Charismatic leadership in organizations. Sage Publications.

Du Monde, M. (2016). The KAP Survey Model (Knowledge, Attitudes, and Practices).

Elkhani, N., Soltani, S., \& Ahmad, M. N. (2014). The effects of transformational leadership and ERP system self-efficacy on ERP system usage. Journal of Enterprise Information Management, 27(6), 759-785.

Ghasemy, M., \& Hussin, S. (2014). Change, Leadership and Change-oriented Leadership Theories in Higher Education: A Review.

Gibson, C.B., \& Cohen, S.G.(2003). Virtual Teams That Work: Creating Conditions for Virtual Team Effectiveness. John Wiley \& Sons.

Gurr, D.(2004). ICT, leadership in education and e-leadership discourse. Studies in The Cultural Politics of Education, 25(1),113-124.

Howell, J.M., \& Avolio, B.J. (1993).Transformational leadership, transactional leadership, locus of control and support for innovation: Key predictors of consolidated businessunit performance. Journal of Applied Psychology, 891-902.

Higgs, M., \& Rowland, D.(2000). Building change leadership capability: The quest for change competence. Journal of Change Management, 1(2), 116-130.

Ilies, R., Judge, T., \& Wagner, D.(2006). Making Sense of Motivational Leadership: The Trail from Transformational Leaders to Motivated Followers. Journal of Leadership \& Organizational studies, 13(1), 1-22.

Jarvenpaa, S.L., \& Tanriverdi, H.(2003). Leading virtual knowledge networks. Organizational Dynamics, 31(4), 403.

Kaliyaperumal, K.I.E.C. (2004). Guideline for conducting a knowledge, attitude and practice (KAP) study. AECS Illumination, 4(1), 7-9.

Kayworth, T.R. \& Leidner, D.E.(2002). Leadership effectiveness in global virtual teams. Journal of Management InformationSsystems, 18(3),7-40.

Kerfoot, K.M.(2010). Listening to see: The key to virtual leadership. Nursing Economics, 28(2), 114-117.

Kevin K.,Barling, J., Kelley, E., Comtois, J., \& Gatien, B.(2003). Remote transformational leadership. Leadership \& Organization Development Journal, 24(3), 163-171.

Khan, Y.H., Sarriff, A., Khan, A.H., \& Mallhi, T.H.(2014). Knowledge, attitude and practice (KAP) survey of osteoporosis among students of a tertiary institution in Malaysia. Tropical Journal of Pharmaceutical Research, 13(1),155-162.

Lepsinger, R., \& DeRosa, D. (2015). How to lead an effective virtual team. Ivey Business Journal, 2-6.

Malhotra, A., Majchrzak, A., \& Rosen, B.(2007). Leading virtual teams. Academy of Management Perspectives, 21(1), 60-70.

86 NJMSR V. 3 Issue 2 (2019) 
E-leadership in Social Change: A New Paradigm in Bangladesh

McDonough,E. F., Kahn, K. B., \& Barczak, G. (2001). An investigation of the use of global, virtual, and colocated new product development teams. Journal of Product Innovation Management, 18(2), 110-120.

McLuhan, M.( 1963). The Gutenberg Galaxy. Toronto: University of Toronto.

McRoberts, S., Bonsignore, E., Peyton, T., \& Yarosh, S. (2016). Do It for the viewers!: Audience engagement behaviors of young YouTubers. In Proceedings of the The 15th International Conference on Interaction Design and Children, 334-343. ACM.

O'Keeffe, G.S., \& Clarke-Pearson, K.(2011). The impact of social media on children, adolescents, and families. Pediatrics, 127(4), 800-804.

Piccoli, G., Powell, A., \& Ives, B.(2004). Virtual Teams: Team control structure, work processes, and team effectiveness. Information Technology \& People, 17(4),359379.

Poushter, J., Bishop, C., \& Chwe, H.(2018). Social media use continues to rise in developing countries but plateaus across developed ones. Pew Research Center, 22.

Pulley, M., \& Sessa, V. I. (2001). E-leadership: Tackling complex challenges. Industrial and commercial training, Journal of Business, 33(6).

Podsakoff, P.M., \& MacKenzie, S.B.(1994). An examination of the psychometric properties and nomological validity of some revised and reduced substitutes for leadership scales. Journal of Applied Psychology, 79 (5), 702.

Shabir, G., Hameed, Y.M.Y., Safdar, G., \& Gilani, S.M.F.S.( 2014). The impact of social media on youth: A case study of bahawalpur city. Asian Journal of Social Sciences \& Humanities, 3(4), 132-151.

Toffler, A., \& Alvin, T.(1980). The Third Wave . New York, NY: Bantam Books.

Trist, E. L. (1963). Organizational Choice. London: Tavistock.

Weber, M.( 2009). The Theory of Social and Economic Organization. Simon and Schuster.

Westenberg, W.M.(2016). The Influence of YouTubers on Teenagers: A Descriptive Research About The Role YouTubers Play in The Life of Their Teenage Viewers (Master's thesis). University of Twente, Netherland.

Zigurs, I.(2003). Leadership in virtual teams: oxymoron or opportunity? Organizational Dynamics, 29(5), 101. 